\title{
In memoriam Peter F. Drucker (1909-2005)
}

Peter F. Drucker, who was often called the world's most influential business scholar and whose thinking transformed corporate management in the latter half of the 20th century, died November $11^{\text {th }}$ at his home in Claremont, California. His work influenced Winston Churchill, Bill Gates, Jack Welch and the Japanese business establishment. He authored more than three dozen books, translated into 30 languages, and received more than 20 honorary degrees in the USA, England, Japan, Belgium, Switzerland, Spain and the Czech Republic.

Peter F. Drucker was born in Vienna on November $19^{\text {th }}, 1909$. He was educated in Austria, Germany, and England. He started his career in Economics (by) working for several German banks and export companies, and, at the same time, as economic journalist for Austrian and German newspapers and international banks in London. In 1929, he won a doctoral degree in Law at the University of Berlin. Due to the rising German anti-semitism after Hitler's coming to power in 1933, he left Germany and went to England, where he worked as a consultant for British banks and insurance companies. In 1938, he moved to the United States, starting his professional career as a consultant for American companies while still working as an economic journalist. Industrial giants like General Motors, IBM, Caterpillar, Merck, and Hewlett Packard sought his advice. To this day, his commentaries in the British and American press are valued and cited for their critique and visionary content. During World War II, he worked for the US State Department's intelligence.

Also during World War II, in 1942, he started his career as a university professor at Bennington College. From 1949, he read Management at the New York University. In 1971, Peter Drucker moved to California, where he helped to develop the country's first executive master's of business administration program for working professionals at Claremont Graduate University. Its management school, where he taught until 2002, is named after him.

Mr. Drucker pioneered the idea of privatization and the corporation as a social institution. He coined the terms "knowledge workers" and "management by objectives". Central to his philosophy was the belief that highly skilled people are an organization's most valuable resource and that a manager's job is to prepare and free people to perform. Good management could bring economic progress and social harmony, he said, adding that "although I believe in the free market, I have serious reservations about capitalism.". Mr. Drucker demanded that public and private organizations operate ethically and decried managers who reap bonuses by laying off employees. "This is morally and socially unforgivable, and we will pay a heavy price for it," he said. Although he was not always right with his visions, "in the world of management gurus, there is no 
debate. Peter Drucker is the one guru to whom other gurus kowtow," said the McKinsley Quarterly in 1996.

Commemorating Prof. Peter F. Drucker, JEEMS reprints hereafter an interview taken with him in 1997 when he was receiving an honorary degree from the University of Economics Prague. The questions were asked by Radim Vlcek, Jan Trunecek as well as by our advisory board member Ivan Nový.

Thomas Steger (Co-ordinator) 
Prof Drucker, you have defined management as a practice rather than a science. Do you think that this definition will be held in the future? Which trends can be expected in the development of management? In your opinion, which will dominate, rather hard or rather soft elements of prosperity in today's understanding?

Peter F. Drucker: Management is definitely not a "science", as the word "science" is used in the English-speaking countries. It is equally not an "art". It is a Practice. In that, it is similar to medicine, which it resembles in a good many other respects as well - for instance, in the need in many situations for a careful diagnosis, rather than a standard prescription. And, as in medicine, the results are not "scientific". A successful doctor is one who cures his patients. A successful executive or manager is one whose enterprise prospers. In medicine you have a good number of foundation disciplines which are the "medical sciences": chemistry, physiology, anatomy, and so on. But the end result is not knowledge as it is in a "science". It is a cured patient. Management, similarly, has a substantial number of foundation disciplines. A successful manager must know a fair amount of psychology, for instance; a fair amount of economics; a fair amount of statistics - which, by the way is the one area where most executives today are most deficient. But at the same time, these are foundations rather than the practice itself.

Management resembles medicine also, in that there is both a "hard" side to it and a "soft" side to it. The physician needs a lot of standard data, from taking the patient's temperature, to taking the patient's weight, and to prescribing a specific diet, or a specific medicine. But the physician also needs to look at the patient as a human being, and not as an inanimate object. Similarly, the executive in any organization, whether a business, a non-profit organization, or a government agency, needs both "soft" and "hard" skills.

In both areas we are in a period of tremendous changes. Look at the "hard" areas first. Globalization - and it is no longer future but very much present - demands a good deal of very "hard" knowledge - of markets; of customers; of noncustomers; of changing technologies. It demands clear and quantifiable goals. It demands a fair amount of very "hard" skills such as cash-flow management and foreign-exchange management.

At the same time there are fundamental changes in the composition of the work force. The center of gravity of the working population is rapidly shifting from people who work with their hands to people who are "knowledge workers".

This demands an enormous number of new "soft" skills. The knowledge worker has to be managed quite differently from the manual worker. Productivity of knowledge work - and we so far know little about it - is basically different from the productivity of the manual worker, whether the manual worker is a farmer, a factory worker on the assembly line, or the clerk in the retail store who brings 
the merchandise from the stockroom into the store and puts it on the shelf. In all manual work - whether in the factory or on the farm - work programs the worker. The task determines what the worker does. The question for the last hundred years, that is for the period in which we have been working on the productivity of manual work, is not what the job should be. It is how it should be done.

The knowledge worker is not programmed by the job. The knowledge worker, whether we talk of a manager in a business, or of a professor in the classroom, very largely has to determine what the task is. For the manual worker we took this for granted. For the knowledge worker it has to be defined. This is a challenge both for the knowledge workers themselves, and for the people with whom they work.

And in all fields we are facing a period of tremendous change in basic technologies - information technology is only one of them, though perhaps the most visible one. Manufacturing, as a technology - last studied and changed in the early 1920s - is rapidly becoming different, both in theory and in practice.

The most radical change, however, is one very few executives so far pay any attention to. It is the change in the oldest part of a modern enterprise, the accounting system. Fundamentally, our accounting system goes back to the 13th century. The only change since then is now seventy years old: manufacturing cost accounting was developed in the 1920s, both in the US and in Germany. Both the traditional accounting and the traditional cost accounting are hopelessly obsolete. The new accounting is however emerging fast. There is activity-based accounting, which is about to replace traditional cost accounting. It also gives us, for the first time, decent cost information about non-manufacturing organizations whether a department store, a bank, a hospital, or a university.

Economic-chain accounting is coming equally fast. Our traditional accounting system focuses on the legal entity, that is, the individual firm.

But this is a meaningful entity only for shareholders, for creditors, and for employees - but for nobody else, and above all not for the customer. Within the economic chain, from raw material to ultimate consumer or user, even the biggest firm is only a fairly small link. And so, to be able to manage costs increasingly critical in a world which is becoming globally competitive - we need to know what the real costs are. Economic-chain accounting - originally developed in the US some sixty years ago and now practiced above all by the Japanese - enables us to put activities where the ratio between costs and results is most favorable. This underlies, for instance, the entire move toward outsourcing that is so prominent in the US today, and is beginning to be equally prominent in Japan.

Another major accounting innovation: we have to move from pricing that is based on costs, which is what we have been doing for hundreds of years, to 
costing that is based on price. We have to start out with what the customer is willing or able to pay, and then go back step by step to fit the costs to the predetermined price.

Equally important, and equally "hard," is the growing need to define in an enterprise both, what its basic assumptions are regarding the outside world, regarding markets; regarding customers; regarding competition. And then the enterprise has to define what its core competencies are. Finally, it has to match its core competencies to the assumptions regarding the outside world on which a business bases itself. I call this the Theory of the Business - and it is in rapid flux and change.

But so are the "soft" skills. Not very long ago, I sat down with a very old and very big client, one of the world's biggest automobile manufacturers. And we spent several days to think through what business policy and business strategy might have to be when people no longer buy their automobiles from a dealer, but buy them on the Internet as they are already beginning to do, both in Japan and in the US. We started out with the assumption that in fifteen years from now there might be no automobile dealer left. But then, we will still have to service the car. We will still have to repair it. And we will still have to organize a usedcar market. These changes will require very considerable and novel "hard" skills. But equally, we concluded, such changes will require an almost total rethinking of the relationship between manufacturer, distributor, and customer. It would require, also, almost totally different promotion.

In other words, any change today requires that we use "both hands," the "soft" one and the "hard" one.

Just look at the implications of the fact that with modern information technology there is no need anymore for the big central office. The skyscrapers which we built so assiduously since the end of the Second World War, are likely to be obsolete in another fifteen years. There is no reason why people who do support work, bookkeeping and accounting for instance, need to commute into the big city the way they now do all over the world. It is much easier and much cheaper to bring the work to them.

North America's largest insurance company - probably the world's largest life insurance company altogether - does not handle its claims in ist New York head office. It sends them on an airplane to Ireland. Leaving New York at six in the evening, they arrive - with an eight-hour time differential - at Shannon Airport at eight in the morning, Irish time. By nine, they are already being worked on in a number of small decentralized offices all over the countryside. Ireland has both the highest unemployment rate in Western Europe, and extremely well educated people so that there is no shortage of people who can do this work. At five in the afternoon the same day, the claims are all settled. Each has been put into an envelope together with the check. Because of the time difference they arrive 
back in New York an hour earlier than they left Ireland. The same evening, they are being sent out all over the US by one of the courier services.

Similarly, there is no reason any more why any one university should do its supporting work in-house. In the US I have been working with a number of medium-sized universities - colleges with 2,000 to 5,000 students - centralizing their support work wherever there is a good supply of clerical workers - and that means a small town, rather than the downtown campus where the university itself is located. But how do you supervise people like these?

We are outsourcing more and more work which means that more and more people who work with a company are not employed by the company, but by the outsourcing contractor. How do you lead such people, many of whom may work for the same outsourcing customer for many years, but who are still not its employees? Increasingly we see alliances, joint ventures, partnerships of all kinds - in part because this is the only way to do business in a lot of countries, and in part because no one company any more can generate all the technology it needs. So companies - and not only companies but hospitals and universities as well - find themselves working with partners whom they cannot command. A partnership is a marketing relationship and not a command relationship.

We will, in conclusion, have to develop increasingly both far greater and very different "hard" skills, and far greater and very different "soft" skills. This is why the management school is so important. It is the one place where these new skills can effectively be developed and effectively be taught and effectively be disseminated.

Knowledge is, and will be one of the basic sources of a postcapitalist society. What's your opinion regarding the role of education in this context?

Peter F. Drucker: One definition of knowledge work is that it requires formal education. No one has ever learned the multiplication table by "apprenticeship." No one has ever learned anatomy by "apprenticeship." More and more of the competencies we need have to be based on a formal learning. So education is surely going to be the center of any developed economy.

If I may put in an important aside. The fastest developing area of the world in the last ten or fifteen years has been Mainland China. And yet, one has to be very careful about going into China, and not only because of the political uncertainties. The supply of educated people is simply not there. The quality of the Chinese student is unbelievably high. But there simply are not enough of them to staff a modern economy. China has a population of a billion, twohundred million people. But it has not even half as many university students as has Japan, with about $10 \%$ of China's population, and less than one-tenth as many university students as the US, which has not quite one-fifth of China's population. Anyone who has gone to China to do business has found that you 
can get a few top people of very high quality. But you cannot get middle management. You cannot get technical people. And this is the major reason why I am still very reluctant to accept the wide-spread belief that in ten years from now China is going to be an economic super-power.

What even you in the Czech Republic may not know - very few people do - is that the modern educational system is a Czech product. Have you ever heard of Amos Comenius - his original name, of course, was Komenich - the great Czech educational reformer? A Hussite pastor, he fled Prague when the Habsburg suppressed the Czech uprising in 1620. He spent the rest of his life in England and Holland. It was Comenius who created the modern school. He invented the primer and the textbook. And he was the first man in history to advocate universal compulsory education. We now badly need a new Comenius. We have to integrate the tremendous opportunities of information technology into the educational system. The printed book - invented in the West, 550 years ago - did not revolutionize the school until Comenius, 200 years later. The computer and the Internet will revolutionize elementary school much faster for the simple reason that the computer is unbelievably "child-friendly" - one only has to look at the sheer happiness of a nine-year-old working on and with a computer. This, in turn, will enable the teacher to be many times more effective. Routine learning the computer does better than any teacher, with infinitely more patience. This, in turn, enables the teacher to concentrate on the strengths of a child. It enables the teacher to teach. Today teachers, especially in elementary schools, spend most of their time on custodial tasks such as keeping order in the classroom. The computer does a much better job at that.

But equally, we have to change our image of education. Most people still believe that one stops learning when one begins working. We still look upon each kind of school, the elementary school, the gymnasium, the university, as terminal. We will have to learn that real learning begins when traditional schooling ends. We then have to learn that the institutions of education, and especially the universities, will accompany the educated people all their lives. These educated people, whether they are engineers, or physicians, or marketing people, or chief executives - in fact, especially chief executives - will have to come back to the university again, and again, and again. In fact, every highly-educated person who has been out of school more than five years - the engineer, the chemist, the computer scientist, the physician, the lawyer, and so on, are becoming obsolete, and need to go back to school to learn again.

One of the fundamental differences between the traditional society - the one we have now had more or less for 5,000 or 6,000 years - and the knowledge society which we are entering, is that skills are fundamentally different from knowledge. Skills change very slowly. My name, as you know, means Printer, and my ancestors were printers in Amsterdam, for almost 250 years, from 1517 to the middle of the 18th century. During that entire period not one of my ancestors 
had to learn anything new. Printing did not change until the middle of the 19th century, that is, until another hundred years after my ancestors' firm went out of business.

Socrates, as we all know, was a stone mason. If he came back to life again and went to work in a masons' yard, he would find that absolutely nothing has changed. He'd use the same tools to turn out the same product. But a nephew of mine, who is a distinguished radiologist in the New York City area, and professor of radiology at one of our leading medical schools, goes back to school as a student every three years for three to six weeks. Otherwise he would soon be hopelessly out of date. The same is true of the engineer. The same is true of everybody who is getting paid for putting knowledge to work. The school; its productivity; its focus; its competence; and above all its willingness to educate the adult, will become the critical element in every advanced and developed society, as it already is the critical organ of development in the emerging countries. The achievements of Japan, of Korea, and now of Thailand or Malaysia, all rest on their educational system and especially on the university system.

At the end of the Korean War in 1953, Korea was the world's most destroyed country - far more destroyed than Germany or Japan or Russia were at the end of World War II. And it was 90\% rural. Today, forty years later, it is a fully developed country. The secret: for ten years we had 300,000 young Koreans as guests of the United States in American universities. In my classes at New York University during those years I always had twenty or thirty Koreans in every course. And so, Korea could compress into thirty years what it had taken the Japanese a century, and what it had taken the West 200 or 250 years.

The knowledge society as it is developing is a society in which schools - from kindergarten to post-graduate - are what the church was to the Middle Ages. Very few schools (and even fewer teachers) know that as yet, or are willing to think through what it means for the way they do their own job. This is going to be one of our major tasks ahead.

In your book „Postcapitalist Society“ you have written: “The function of capital will be more and more in creating conditions for effective use of knowledge. Management will use capital in a higher degree for the support of its own efficiency than for its control." This new social structure you have called "a socialism of pension funds" and in the above mentioned book you prefer the term "capitalism of employees". Could you explain your view about this problem?

Peter F. Drucker: I chose the term "Pension Fund Socialism" quite deliberately to shock people twelve years ago. I wanted them to realize that something totally unexpected had happened. Let me say by way of explanation that ten or twelve years ago, practically nobody in the United States had realized that the pension 
funds had become the dominant owners of the equity capital of American Industry, and the dominant lenders to industry, especially big companies, as well.

Also, the term "Socialism" is technically completely correct. Socialist doctrine defines "Socialism" as ownership by the employees (or workers) of the means of production. This, of course, is what has happened. The employees of America (but also of Japan or of Chile, to name but two other countries) through their pension funds are the owners of industry, and especially of the big companies. My use of the term "Socialism" had the desired shock effect. Twelve years ago, when I coined the term, nobody was aware of the profound shift in the basic ownership and therefore in the basic social structure of the most highlydeveloped countries. By now, there is hardly any issue of a legal or an economic journal without a heated discussion of the implications of the shift of economic power to the pension fund; of what it means for the law; for society; for the economy, and for the governance of corporations.

And yet, in retrospect, my coining that term was a mistake. Very few people, it seems, realize what "Socialism" originally meant, and what it still means in Socialist doctrine. For most people, "Socialism" means ownership of the means of production by the State.

However, to call the new economic structure "Employee Capitalism," as I did in one of my later books, is probably also a mistake. Here is something that has happened - and it is a profound change. But we have no term for it yet. In fact, we do not yet understand it. In the recent re-issue of the Pension Fund book, I changed the title to "The Pension Fund Revolution," and side-stepped the nasty question what this new economic structure means and what it should be called. It will need a name, but above all it will have to be understood. And while I tried eleven or twelve years ago, to analyze it - and so far my analysis has worn well the real implications still have to be thought through. The relations of the Pension Fund to its beneficiaries, that is, to the present employees who are going to be its future beneficiaries, and to the businesses which finance the Pension Fund, are still to be clarified and defined. But at least we have reached the point where we know that here is a new and important phenomenon. And we know that we have to come to grips with its legal, social, economic, and political problems.

The management of non-profit organizations is a problem in the Czech Republic as well. You wrote a whole book about this problem. Could you in more detail describe the most important problem connected with non-profit organization management?

Peter F. Drucker: Today's developed society has to have three major sectors. It has, so to speak, three legs to stand on: a public sector, that is government; a private sector, that is the economy; and a social sector, which will largely consist 
of non-profit organizations. For the tasks of the community cannot effectively be discharged by either government or business. Fifty years ago, when I published my first book that tried to analyze modern industrial society - it's title was „The Future of Industrial Man" and it came out in 1943 - I had high hopes that the large business enterprise could provide the community needed. I then talked of the "self-governing plant community."

In only one country was this book taken seriously: Japan. How it reached Japan in the middle of World War II, I have never been able to figure out. But it did, and it became the main source for the specifically Japanese organization of the large business enterprise as the home, the community, and indeed, the family of the employee. (Before World War II, there was no country in which the worker had less job security and was considered more dispensable than Japan.) But even in Japan, this idea has not really worked out. Today, Japanese businesses are confronted with the fact that they will have to downsize, will have to move workers out of yesterday's major industries such as steel and automobiles into tomorrow's industries, and so on.

Outside of Japan, during the last forty years, we have looked to government as the organ to handle the problems and opportunities of the community - of course at its most extreme in the Communist countries. But we in the United States, too, have primarily looked to government to handle community problems. It has not worked. Community is local and requires local action by local institutions. Community is based on the individual and not on a collective. And community has so many different dimensions. It needs a different kind of organization. It needs non-profit organizations.

This of course is nothing terribly new. In fact, if you want to look for a nation in which the non-profits created community, look at your own Czech Republic as it was before World War II. Growing up in Austria, I visited your country many times then - I still consider Prague the world's most beautiful city. And in those days there was no more effective community organization any place than the Sokols.

The society in which community organizations have to function has changed greatly. When I was born a few years before World War II, there was no country in which the majority of the population did not live on the land. And there was also no country in which the great majority - 90 to $95 \%$ - did not make its living with its hands making or moving things. Today, in the developed countries - and the Czech Republic socially surely belongs among them, and by now also economically - a fairly small minority still lives on the land, and an increasing majority of the population does not make its living working with its hands. It makes its living increasingly by putting knowledge to work.

In the traditional society, since the days of Abraham, if not even further back, community was compulsory. You were born into it, and you stayed in it. Today 
community has to be voluntary. The traditional communities no longer suffice. We have to create a social sector both to tackle the problems of a rapidly changing high-technology knowledge-based society (something we never have had and do not yet really understand), and to give the individual a meaningful sphere of local effective action. It is this line of reasoning that has led me, for almost fifty years now, to devote an increasing part of my own time and energy in the non-profit sector - as advisor to hospitals; to schools and universities; to churches, and to all kinds of community organizations - the United States Girl Scouts, for instance, who are the largest female organization in the world (and the best-run, large non-profit organization I know).

What are their problems? First, results in the non-profit organization, are not given. They have to be defined. In a business there is a bottom line. It is not a particularly good measurement of results. But at least it is a measurement. In the non-profit, the organization itself has to define what it means by "results." And far too many non-profits believe that good intentions are a substitute for results. But the basic challenge for a non-profit organization is to make a difference in society, and that means to have performance and results.

The second challenge is to be able to change. In a market economy businesses that don't change die fast. But non-profits can still be around a long time after they actually become irrelevant. Yesterday's problems are rarely today's problems, and never tomorrow's problems. Yes, the poor will always be with us. But the needs of the poor and their responses have changed dramatically even during the last few decades. So, a non-profit organization has to think through very carefully what its mission is, and what it should be.

Just now, I am teaching a fairly large class - fifty people - in my executive management program, a class composed primarily of senior non-profit managers. I have just spent a long week reading their essays. Every one of them, without exception, talks about the need to rethink, to redefine, the mission of the organization, and to rethink and to redefine what results are and what they should be.

And the last challenge, at least in the US (and this is the only society in which I have actively worked in the non-profit sector), is that the success of non-profit needs both, a small but highly competent group of permanent, professional employees, and a much larger group of volunteers. We know how to manage volunteers. And we know how to manage the permanent staff people. But the relationship between those two is complex and highly problematical.

But if you are going to ask me to name the one fundamental, the one truly important challenge, it would be the need for a clear mission and for a clear focus on results. This is the reason why a foundation for non-profit management which some friends and I founded six years ago - my friends were kind enough to name it after me so that it is called „The Peter F Drucker Foundation for Non- 
Profit Management" - tackled as its first task the development of a simple selfassessment tool for non-profits, and especially for the small, local non-profit organizations which we have more than a million in the US. All of them are full of good intentions. Very few of them, I am afraid, yet produce results commensurate with their good intentions or with their hard work. Very few, in other words, have really yet analyzed their mission and their performance - which is what the self-assessment tool of the Drucker Foundation now enables them to do.

Last time we were witnesses of a new revolution in entrepreneurship: reengineering. Inflation of literature on this branch is at the least surprising. Do you consider reengineering to be the fundamental shift of paradigm or only the next fashion applicable by marketing?

Peter F. Drucker: No. Reengineering is not the most profound change to date. In fact, the way it is being used today in the US is more abuse than proper use. It is used by many organizations - and by no means only by businesses - as an excuse for firing people. It is used by a very, very few to do what it was designed to do, that is, to analyze the structure of the organization and to adapt it to the flow of work and, above all, to adapt it to the desired results and to the performance of the organization.

What is, however, clearly happening is that we are being forced by a number of changes to re-think almost every business including even small and local ones. One reason for this is globalization. Even the most local business today is basically competing world-wide. A competitor can come in overnight from any place in the world. Another major factor, of course, are the tremendous changes in technology, of which the information technology is but one example.

The fastest growing industry in the last fifteen years has not been information. It has been finance. But it is a totally different finance from that of the 19th century, which still in large measure represents the financial system in most countries - the traditional commercial bank. The fastest growing financial institutions have been institutions which either develop and supply investments for the rapidly growing number of older people who need to protect themselves financially against living too long. Or, they are institutions which provide the financial technologies needed in a global economy such as, for instance, the management of foreign exchange exposures.

Every business - with very few exceptions - will therefore during the next decade or so, have to think through both its basic focus and its basic structure. Reengineering was meant to be the first step in that direction. But that is all it is.

Re-thinking what I call the theory of the business, re-thinking its mission; its core competencies; its focus; that is what all businesses will have to do within the next ten or fifteen years. In the process, there will be quite a bit of 
reengineering. But the profound changes will not come out of analyzing operations - which is what reengineering does. It will come out of analyzing mission and out of re-defining results.

Let me give you one example. The world's largest manufacturer of heavy earthmoving equipment is an American company. Its name is Caterpillar. Thirty years ago it had about two-thirds of the world's market for its products, such as the very heavy equipment needed to build a super-highway or to build a skyscraper. Then it was challenged by a Japanese company called Komatsu. And within a few short years, Caterpillar saw its share of the world market shrink from seventy to thirty-five percent. Caterpillar now has again seventy percent of the market - and of a much bigger market. What happened is that Caterpillar rethought its business. It asked: What are results for the customer? The answer was that for the contractor who builds twenty kilometers of super-highway in Malaysia, "results" means keeping the equipment running. Any breakdown of the equipment costs the contractor infinitely more than the equipment does. Caterpillar totally rebuilt itself as a service company. Sure, it still manufactures the same equipment, but it does not do it the same way. Its main plants now make parts. They are being assembled in new and small shops close to where the customers are. And those shops are strategically deployed so that any breakdown of equipment anyplace brings a Caterpillar-trained service engineer and Caterpillar replacement parts to the contractor's place of business within twelve or, at the very latest, eighteen hours.

This in turn meant that the equipment had to be redesigned. It meant that the organization had to be redesigned with service people in the field as he center of the entire company. It took ten or fifteen years of very hard work to bring this about. The result is a totally new Caterpillar Company, a company that has regained its world leadership.

The society of knowledge will require a new management philosophy and a new type of production manager who will have to understand and use in practice the discipline of which will integrate the knowledge of engineering, people leading and economics of the firm. Such discipline as you have mentioned hasn't been systemated yet, it isn't taught at any technical school, business school or faculty all over the world but it serves as a pedagogical appeal for the near future. Could you tell us more detailed information about your idea regarding this discipline?

Peter F. Drucker: I wish I could answer this question. But I can only offer first approaches. It is, however, one of the most critical challenges we face.

Perhaps I may be allowed to start with some personal experience. More than forty-five years ago, in 1950, I joined the faculty of a major business school, the faculty of the Graduate School of Business at New York University. In addition to being appointed the world's first Professor of Management, I was also asked 
to take charge of the school's curriculum. About the first thing I did was to abolish all our classes in manufacturing and production. They had no discipline; no methodology; no content. Now, forty-five years later, at the very small Graduate Management Center at which I still teach, we are putting back the courses in production. We are still very tentative. But now there is emerging a true discipline of production. The dominant manufacturing methodologies of fifty years ago are now quite obsolete. Then the mass-production assembly line was seen as the ultimate in production methodology. I was even then exceedingly critical of it - I considered it even then to be a poor use of human beings, and a very wasteful one. Now, of course, everybody talks of teamwork. But also, the new and growing industries are not mass-production industries, even if they do make products in large quantities. When you look at the most recent plants in the old mass-production industries - for instance at Toyota's new automobile plant in Japan - you will find very little of the traditional massproduction. But you also will find very little automation. They are not built on new machinery. They are built on new concepts.

We do not, so far, have anything that could be called, "a new management philosophy." We do not even have anything that could be called "a new production theory" - though we are getting pretty close to it, close enough, for instance, for me to write a major essay under this title. But this essay only outlines what we need to know, and not yet what we do know. The production manager of the future - and in that respect I see very little difference between the manager in the factory and the manager in the office - will above all need a clear understanding of the desired end results. They will need to start out with the realization that quality does not cost money but makes money, that quality in other words is not a cost center but a profit center. They will need to know how to analyze the entire process so that the work can be done where it is most efficient and most economical to do. We can already do all these things, but so far only piecemeal. But we have had enough success to know that the key to the new theory of production is not materials. It is new concepts

Let me give you one example. The largest manufacturer of locomotives in the world, both of Diesel locomotives and of Electric locomotives, is the American General Electric Company. (The others are General Motors, also an American company; Asea Brown Bovery, a Swedish-Swiss company, Siemens in Germany and Hitachi in Japan.) Thirty years ago General Electric was at the point of closing down its main American plant (in Erie, Pennsylvania), and to concentrate all its locomotive production for the entire world in its Brazilian and Mexican plants, where labor costs were so much lower. Today, the Mexican and Brazilian locomotive plants of the General Electric Company have been closed down. All production for the entire world is concentrated in the United States, despite its high labor costs. This has enabled General Electric to become the world's largest locomotive manufacturer - overtaking its arch-rival General 
Motors. This is not because the Erie plant is highly automated. General Electric thought through the entire process of making a locomotive. In fact, it thought through the entire process of designing a locomotive. It started out with what seemed to be a foolish question, "What is a locomotive?" And nobody could answer it. It then asked, "What does the customer, the railroad, pay for when it buys a locomotive." And nobody could answer that either. It then asked, "What are the physical limitations, the laws of nature, that determine the performance of a locomotive?" And nobody could answer that either. It was not until these questions had been thought through - in bitter battles, by the way, between engineers and production people; between marketing people and engineers; between service people and everybody else - that the question could be asked, "How should the locomotive be designed?" "How should it be built?" The result is a totally new production process that starts out with service specifications rather than with technical specifications. Today the Erie plant of the General Electric Company produces about five times as many locomotives as it could have done twenty-five years ago, with not much more than two-thirds the manpower. This foreshadows the new discipline of making, of producing. It will, by the way, perhaps have its greatest impact not on production in the plant, but on production in the educational system, where nobody so far has asked the basic questions which the people at General Electric asked thirty years ago.

Still we are not yet, I believe, ready to develop a discipline of production. For this we will need another five or ten examples like the General Electric example, and in a lot of different areas. One of them, by the way, is the way the modern mega-retailers - a WalMart in the US; a Carrefours in France, Spain and Brazil; or a Daiei in Japan - have restructured the physical distribution of the merchandise they sell. They have been able to eliminate the warehouse. And that has cut the cost of physical distribution by something like two-thirds.

Another example is the way a few of the major banks, Citibank in the US, for instance, have restructured the handling of the enormous amount of paper - or rather today, of electronic information - which is needed to process eighty million credit cards a week.

But, as I said before, so far we can point to examples of success, but not yet to a basic theory that underlies these examples. In this respect, we are at the point where medicine was in 1900, when the greatest clinician of the time, William Osler (a Canadian who practiced first in the US and then became Professor of Medicine at Oxford), wrote what to this day is probably the best textbook in any major discipline, his „Internal Medicine“. The diagnosis which he developed in that book is still pretty much what all modern medicine uses even though we have, of course, infinitely more highly-developed instruments (there was no electrocardiograph, for instance, in Osler's time). But only now, almost a century later, are we beginning to move medicine towards a fundamental theory of biological processes that enables us to teach medicine not as a large number 
of isolated diseases but as processes based on a very small number of basic systems.

Where would that new discipline of production be taught? I doubt that it will be taught in technical universities. They will continue to be focused on things rather than on concepts. It belongs in a management school. It is essentially a discipline about the managing of major and universal processes. It is a conceptual rather than a mechanical discipline - and if it is to be placed anywhere it should, in all likelihood, be in the academic institution that deals with the management of work and with the production of wealth, that is a management school.

The last - pedagogica - question: Which direction should the education of management go? What should be the structure of education, its content and connection with practice?

Peter F. Drucker: In terms of quantity, the teaching of management has done unbelievably well this last half-century. When I moved into management in 1949-59, I was the first professor of management in the United States, and actually in the world. At that time business schools - nobody then called them "management schools" as we do now - were pretty much at the periphery. Today, in the United States, business is the most popular faculty with the most students, the biggest budgets, the largest number of professors. In Europe the development has been equally drastic. The first thing any of the former Soviet Satellites in Eastern Europe has been doing is to found business schools and management centers - and they are indeed badly needed.

But qualitatively I have certain reservations. In the US at least, so many business schools have tried to be "academically respectable." And that meant, basically, that they have tried hard to have nothing to do with such sordid things as practicing management, managing people, producing goods, selling them. It meant being as far away from the practice as possible, and to be as abstract as possible. As a result we create fantastically beautiful mathematical models which have nothing to do with anything (I have done my fair share, I have to admit).

Secondly, only in the last few years have most American business schools realized that the biggest and most important contribution they can make is the continuing education of successful practitioners.

What I see ahead - and it is badly needed - are two things. First, we will have to learn to tie the teaching of management to the practice of management. The first step to this was probably the requirement (which I think we first laid down when we founded the Claremont Graduate Management Center twenty-six years ago), that MBA students have at least five years of practical experience before coming to graduate school. But that is not enough. We are now trying to create for the 
management students the equivalent of the clinical practice of the medical student. We are now trying, with considerable success, to have our MBA students work as interns in actual organizations, and with specific jobs and tasks, especially during the summer vacation. We are working with equal success by actual organizations hiring small teams of our students during the academic year, and entrusting them with an important task. A team supervised by one of my colleagues has just finished work on an actual merger for a major manufacturing company, and with great success.

This, we have found, is far more effective than "cases". The student or the group of students who work with a company for a year - in our center usually two afternoons a week in the client's place of business, and one evening at the school under the guidance of one of our faculty members - learn infinitely more than they learn from a case, a case after all, compares to an actual business very much the way the corpse in an anatomy lesson compares to the living patient.

We also - and this we have largely accomplished - insist that the bulk of our faculty keep on working in practice, that is, as consultants. To be sure, we need someone to teach economic history and that person is unlikely to have a consulting practice. But so is the anatomist in the medical school. But the professor of Opthamology is expected to have patients. And so is the professor of marketing in the business school expected to have clients. This, I think, is going to be increasingly important.

Finally we will have to accept that our biggest market, and the market in which we can have the greatest impact, are not beginners. They are successful midcareer executives. The Claremont Management Center, which I helped found 26 years ago, was the first management school in the world that was built around an advanced executive program, and the first also that ran the advanced executive program as a regular academic program, leading to degrees and dissertations. When we began we were told that we would never succeed. By now almost every major business school in the United States has copied what we then pioneered.

We were also the first school which insisted that management is not "business management". From the beginning we organized our executive management program to enroll no more than sixty percent people from business, with the rest being people from all kinds of non-business institutions - we have some pastors running large churches; hospital administrators; school and university administrators; some military commanders; non-profit executives, and so on. And they not only learn a great deal, they contribute an enormous amount to the breadth of our program and the stimulation of our business executives.

Where this is being done in Europe so far, it is being done in specialized institutions, and mostly in fairly short courses. I believe that it belongs in the regular management school. I also believe that what we need are a variety of 
choices: short courses, regular academic programs, in which a student works for several years leading to a degree; and programs which we design and tailor for individual clients. At the Claremont Management Center we are, for instance, now working on special programs for a major aerospace manufacturer which will enroll over the years every executive in the company.

Modern technology will help greatly. We can deliver courses given on campus anywhere via satellite - we already do so. We can easily bring together in one class executives from two dozen different companies, without any one of them having to leave their own office.

And so, I believe that tomorrow's business or management schools will have the following characteristics:

One, it will not be a "business" school. It will embrace people from government and non-profits in addition to business people.

Two, built into its work, whether for beginners or for advanced people will be actual practical work for the student, as intern or as consultant. And we will expect such experience on practice as much from the professor as from the student.

Three, the center of tomorrow's management school - as it will be in every professional school, whether a medical school or a law school - will increasingly be the continuing education of already highly-schooled, successful, mid-career executives.

Finally, increasingly our teaching will be both on campus and off-campus, especially the teaching of the mid-career executive. A good deal of it will be in locations close to where the students live, with twenty or thirty students meeting together, e.g., in the auditorium of a local school gymnasium, with the instructor working with them via interactive two-way video and two-way audio. This instructor will probably be working at the same time with half a dozen such groups in half a dozen different locations. I see no reason, for instance, why the Professor at the Economic University in Prague should not be seen and heard at the same time in Brno, in Plzen, in Olomouc, let alone in the small towns of Bohemia and Moravia. We have the technological means today, and the economics are so overwhelmingly favorable, that we will be forced to go that route. 